\title{
PŘEDPOKLÁDANÝ RŮST ÚNAVOVÉ TRHLINY S VYBRANÝMI GEOMETRICKÝMI TVARY V IPE 80
}

\author{
EXPECTED FATIGUE CRACK PROPAGATION WITH SELECTED \\ GEOMETRIC SHAPES IN IPE 80
}

Tereza Juhászová ${ }^{* 1,2}$, Stanislav Seitl ${ }^{1,2}$, Petr Miarka ${ }^{1,2}$

\footnotetext{
"juhaszova@ipm.cz

${ }^{1}$ Institute of Structural Mechanics, Faculty of Civil Engineering, Brno University of Technology, Veveř́ 331/95, Brno, Czech Republic

${ }^{2}$ Institute of Physics of Materials, Czech Academy of Sciences, v. v. i., Žižkova 513/22, Brno, Czech Republic
}

\begin{abstract}
Abstrakt
Př́íspěvek se zabývá únavovým chováním nerezového nosníku I průřrezu s koncentrátorem napětí. Ocelový nosník z IPE 80 je zatížen tříbodovým ohybem a je provedena analýza rychlosti růstu únavové trhliny pro různé tvary jejího čela. V rámci analýzy jsou sledovány hodnoty součinitele intenzity napětí ve vrcholu trhliny pod středem stojiny. Na základě AISI 304 parametrů Parisova vztahu jsou odhadované rychlosti šíření diskontinuity/trhliny v IPE 80. Zatížení a počet cyklů je stanovený pomocí předpokladů únavového chování materiálu a výsledky jsou porovnány s výsledky studií experimentálně provedených laboratorních testů na stejném materiálu.
\end{abstract}

\section{Klíčová slova}

Nerezová ocel, IPE 80, Parisův zákon, trríbodový ohyb, součinitel intenzity napětí

\begin{abstract}
The focus of this contribution is to investigate fatigue behaviour of I cross-section beam. Stainless steel IPE beam with initiate concentrator is loaded in three point bending and the crack growth rate is analysed for various crack front shapes. Stress intensity factor size in the crack tip is being investigated in relation to growth rate of discontinuity. Load number of cycles is predictable basing on hypothesis of fatigue behaviour of material and the results are compared to experimental results of studies performed on compact tension specimen made from the similar material.
\end{abstract}

\section{Key words}

Stainless steel, IPE 80, Paris' law, three-point bending, stress intensity factor

\section{1 ÚVOD}

Nerezová ocel je materiál čím dále tím více využíván v prostředí jak strojírenském, tak i stavařském. zásluhou jeho výhodných mechanicky - chemických vlastností. Hlavní výhodou pro využívání v průmyslu jsou hlavně zvýšená odolnost vůči korozi, svařitelnost, pevnost a pružnost [1], [2]. V architektuře jí můžeme pozorovat u staveb vystavených nepříznivým vlivům okolního prostředí jako jsou mosty, rozvodní systémy, nebo střešní krytiny [3]. Tyto konstrukce jsou často vystavovány cyklickému zatížení, vlivem dopravy nebo povětrnostních podmínek, co může vést k výskytu a rozvoji trhlin a defektů. Nerezové nosné prvky jsou nejčastěji nosníky nebo sloupy, typických průřezů pro ocel, jako jsou válcované I, U, H profily, nebo profily kruhového průřezu.

Pro objasnění únavového chování ocelových prvků pod cyklickým zatížením je potřebné analyzovat prvky typických průřezů. Pro analýzu byl vybrán nosník IPE $80 \mathrm{~s}$ koncentrátorem v prostředku rozpětí. Zatížení bylo vyvozeno tř́ibodovým ohybem a diskontinuita modelována plošně s variovaným tvarem čela trhliny. Parametr pro popis chování napětí v okolí trhliny sloužil součinitel intenzity napětí, v závislosti na délce trhliny [4].

Cílem př́spěvku je nalezení hodnot zatížení, pro které pro jednotlivé tvary dosahují prahové hodnoty součinitele intenzity napětí, po dosažení které se na základě předchozích studií předpokládá růst únavové trhliny. Následně se odhadla rychlost růstu únavové trhliny pro konstantní přírůstek rozměru ve směru zatížení. Výsledky závislosti rychlosti růstu na součiniteli intenzity napětí ve vrcholu trhliny jsou porovnány s výsledky dosaženými v experimentálních studiích a porovnány s předpokladem rozmezí pro použití Parisova zákona. 


\section{LITERÁRNÍ PŘEHLED/POPIS SOUČASNÉHO STAVU}

Základní lomově mechanické a chemické vlastnosti ocelí jsou uvedeny obvykle v materiálových listech. Únavové vlastnosti nejsou běžně dostupné, několik studií na standardních laboratorních vzorcích z nerezové oceli jsou uvedeny např. [5], [6]. Testy byly provedeno na kompaktních vzorcích excentricky tahovým zatížených pro parametr asymetrie $\mathrm{R}=0,1$. $\mathrm{Z}$ uvedených studií byly zjištěny hodnoty součinitele intenzity napětí, u kterého dochází k růstu únavové trhliny pro různé hodnoty rozkmitu napětí. Studie [7], [8] poskytují výsledky ze zkoušek v trí́bodovém ohybu na betonových vzorcích. Pro studie ocelových profilů nejsou opory natolik rozvinuté.

Po předchozích únavových zkouškách IPE $80 \mathrm{v}$ tř́bodovém ohybu $\mathrm{S} / \mathrm{W}=3$, kterých výsledky byli publikovány $\mathrm{v}$ [9], došlo ke ztrátě stability stojiny nosníku před růstem únavové trhliny. Ve studii došlo proto $\mathrm{k}$ hledání optimálního napětového stavu geometrie pro lomové experimenty.

\section{METODIKA}

\section{Materiál}

Materiál profilu použitý ve studii je nerezová ocel AISI 304/ ČSN 17 240/1.4301, která nejpoužívanější nerezovou ocelí [10]. Chemické a mechanické vlastnosti jsou prezentovány v Tab. 1 [9].

Tab. 1 Chemické složení (v \% hmotnosti) a mechanické vlastnosti použitého materiálu z materiálových listů výrobce.

\begin{tabular}{|c|c|c|c|c|c|c|c|c|c|c|c|c|}
\hline Vzorek & C & Si & Mn & $\mathbf{P}$ & $\mathbf{S}$ & $\mathbf{N i}$ & $\mathrm{Cr}$ & $\mathbf{N}$ & $\begin{array}{c}\text { Mez } \\
\text { pevnosti } \\
\text { v tahu } \\
\text { [MPa] }\end{array}$ & $\begin{array}{c}0.2 \% \\
\text { mez } \\
\text { kluzu } \\
{[\mathrm{MPa}]}\end{array}$ & $\begin{array}{c}1.0 \% \\
\text { mez } \\
\text { kluzu } \\
{[\mathrm{MPa}]}\end{array}$ & $\begin{array}{c}\text { Protažení } \\
\text { [\%] }\end{array}$ \\
\hline 1 & 0,017 & 0,44 & 1,55 & 0,27 & 0,002 & 8 & 18.2 & 0.05 & 628 & 255 & 319 & 58 \\
\hline
\end{tabular}

\section{Součinitel intenzity napětí}

V rámci lineární elastické lomové mechaniky koncept součinitele intenzity napětí tvoří v současné době významný prvek pro popis chování únavové trhliny [11]. V teto studii je použit pro popis napětí v okolí čela. Základní kvantifikace součinitele intenzity napětí $K$ pro mód namáhání I viz např. Tadu [12] je

$$
K_{I}=\sigma \sqrt{\pi a} F\left(\frac{a}{W}\right)
$$

kde $\sigma$ je aplikované napětí, $a$ délka trhliny a $F(a / W)$ bezrozměrná funkce závislá na tvaru vyšetřovaného prvku, geometrie, způsobu zatížení a poměru $a / W$, kde $W$ je rozměr tělesa ve směru růstu únavové trhliny. Hodnoty funkce $\mathrm{F}(\mathrm{a} / \mathrm{W})$ jsou však obecně $\mathrm{v}$ literatuře kvantifikovány pouze pro tělesa dvourozměrné [12], [13], neboli třírozměrné s konstantním prưřezem po tlouštce, které můžeme zjednodušit uvažováním jednotkového třetího rozměru. U těles nekonstantní tloušt'ky jsou hodnoty funkce složitěji kvantifikovány.

Poprvé byl součinitel intenzity napětí představen Irwinem [14], který kvantifikoval závislost pro napětí

$\mathrm{v}$ rovině na $\mathrm{K}$ jako

$$
\begin{aligned}
& \sigma_{x}=\frac{K}{\sqrt{2 \pi r}} \cos \frac{\theta}{2}\left[1-\sin \frac{\theta}{2} \sin \frac{3 \theta}{2}\right], \\
& \sigma_{y}=\frac{K}{\sqrt{2 \pi r}} \cos \frac{\theta}{2}\left[1+\sin \frac{\theta}{2} \sin \frac{3 \theta}{2}\right],
\end{aligned}
$$

kde $\theta$ a $r$ jsou souřadnice polárního souřadného systému s vrcholem $\mathrm{v}$ kořenu trhliny. Pokud uvedené vztahy určíme pro úhel $0^{\circ}$, dostaneme vztah $\mathrm{k}$ otevíracímu napětí

$$
\sigma_{y}=\frac{K}{\sqrt{2 \pi r}},
$$

který byl využitý ve studii pro určení hodnot součinitele intenzity napětí.

Pro dosažení hodnot součinitele intenzity napětí v kořenu trhliny, byla určená cesta napětí délky $1 \mathrm{~mm}$ od kořene trhliny. Ze softwarového prostředí pak byli vzaty výsledné hodnoty otevíracího napětí na této cestě. Pro upřesnění výsledků byla zanedbána oblast tzv. "plastické zóny", co je oblast nejbliže ku kořenu trhliny, kde nastává prudký růst napětí a neplatí zde předpoklady lineárně elastické lomové mechaniky. Hodnoty napětí byli dosazeny 
do rovnice a v závislosti na vzdálenosti bodu od kořene trhliny $r$ bylo vypočten součinitel intenzity napětí pro konkrétní uzel. Metodou nejmenších čtverců byla pak aproximována závislost $K$ na $r$ lineární závislostí a hodnota jejího konstantního členu byla vyhodnocena za sledovanou hodnotu součinitele intenzity napětí ve vrcholu trhliny.

\section{Parisův zákon}

Parisův zákon [15] popisuje vztah mezi změnou délky trhliny a za počet zatěžovacích cyklů $N$ a hodnotami součinitele intenzity napětí $K$ rovnicí

$$
\frac{d a}{d N}=\mathrm{C}(\Delta \mathrm{K})^{m}
$$

kde $C$ a $m$ jsou konstantní hodnoty určené empiricky a $\Delta K$ je rozdíl $K_{\max }-K_{\min }$ pro daný cyklus. Uvedený vztah (5) se omezuje pouze na oblast střední rychlosti šíření únavové trhliny, kde nastává závislost dobře aproximovatelná lineární. Uvedená závislost se používá k vyhodnocování lomových zkoušek a jejich aplikaci v praxi [16]. Použitelnost uvedené závislosti se ukázala být dobrým prostředkem k vyhodnocování únavových zkoušek kovových materiálů [17]. Omezení hodnot definičního oboru funkce $\Delta K$ je zdola prahovou hodnotou $\Delta K_{p}$, po dosažení které dojde k šiření únavové trhliny stabilně, a seshora hodnotou $\Delta K_{c f}$, hodnotou únavové lomové houževnatosti, po překročení které trhlina ztrácí stabilitu a nastává lom materiálu. Obecně její hodnota není totožná s hodnotou lomové houževnatosti $K_{I c}$, což je hodnota lomové houževnatosti u statického zatížení a poměr $\frac{K_{c f}}{K_{I c}}$ může nabývat hodnoty i výrazně nižší než 1 [15].

\section{Kalibrační křivky pro různá čela trhlin}

Parametrická studie byla provedená v programovém prostředí Ansys Mechanical APDL, který pracuje na principu metody konečných prvků. Lineárně - elastické chování materiálu bylo zabezpečeno zvolením typu konečných prvků zvaného SOLID 186.

Materiál byl určen materiálovými charakteristiky, a to konkrétně Poissonovým součinitelem $v=0,3$ a Youngovým modulem $E=210 \mathrm{GPa}$.

Geometrie IPE 80 je znázorněná na Obr.1. Pro urychlení výpočtů a zjednodušení modelu byl vytvořen model pouze čtvrtinového tělesa, čím byla využita jeho symetrie. Znamená to, že jeho zbylá polovina ve směru rozpětí, rovněž jako ve směru průřezu, byla nahrazená okrajovými podmínkami, zabraňujícími posunům ve směru zbývající části. Podepření tělesa bylo opět nahrazeno okrajovou podmínkou zabraňující svislým posunům. Poměr rozpětí S k výšce tělesa $\mathrm{W}$ byl zvolen jako tř́násobný, odpovídající reálným vzorkům, na kterých budou provedeny reální experimenty. Působící zatížení simulující trríbodový ohyb bylo vyvozeno jako liniové uprostřed rozpětí,

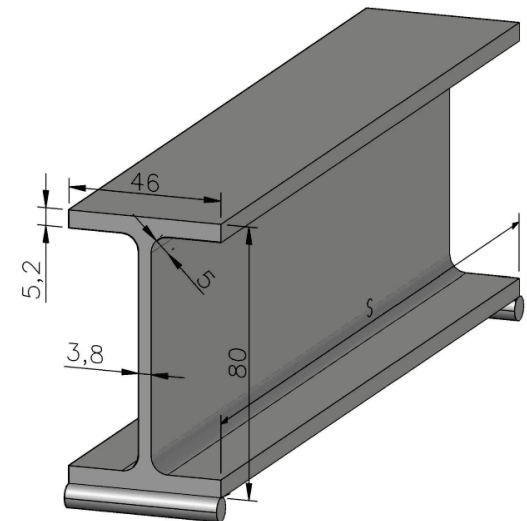

Obr. 1 Geometrie IPE profilu se znázorněným podepřením.

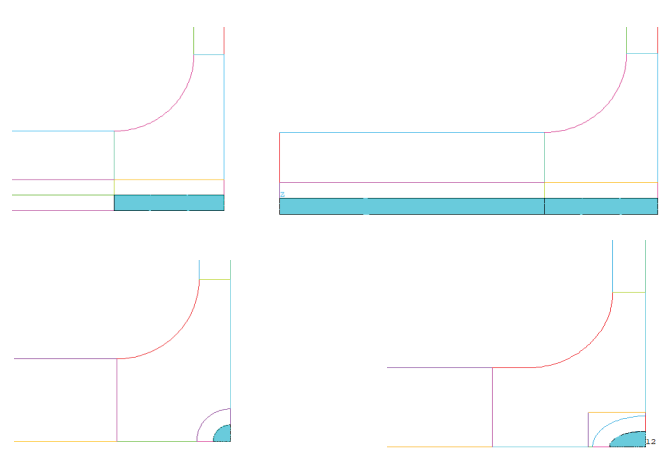

Obr. 2 Vybrané tvary čel trhliny pro analýzu ze SW prostředí ANSYS.

aplikováno na horní hranu profilu. Trhlina byla modelována jako plošná, bez okrajových podmínek, se čtyřmi variacemi tvaru trhliny, a to konkrétně rovným, prorůstajícím celou tloušstkou průřezu, kruhovým, obdélníkovým a elipsoidním. Zmíněné tvary jsou graficky znázorněné na Obr 2. Jelikož byli sledovány hodnoty napětí v blízkosti čela trhliny, byla sít' konečných prvků nejvíc zjemněná v tudíž oblasti. 


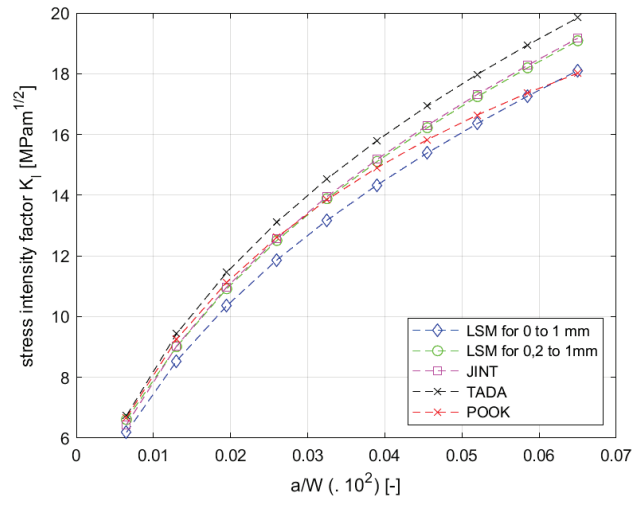

Obr. 3 Hodnoty součinitele intenzity napětí pro různé tvary čela trhliny $\mathrm{v}$ IPE.

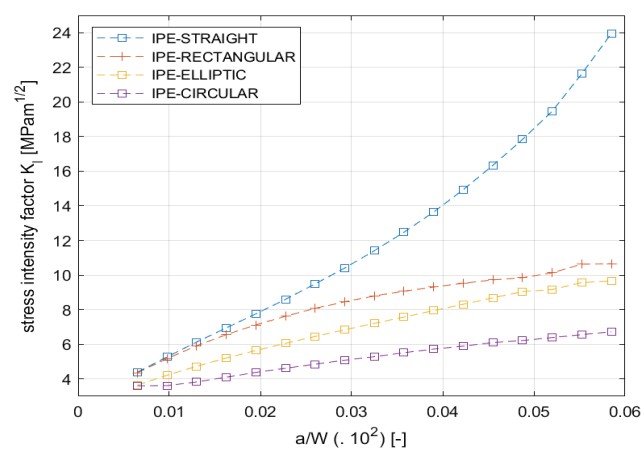

Obr. 5 Hodnoty součinitele intenzity napětí pro různé tvary čela trhliny v IPE 80.

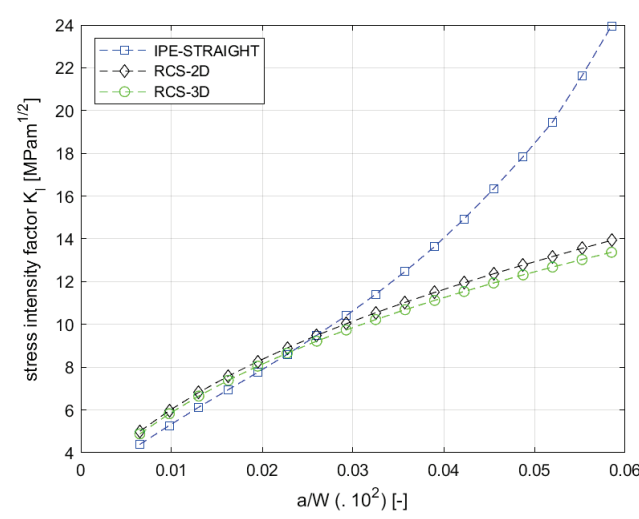

Obr. 4 Hodnoty součinitele intenzity napětí pro modely s rovným čelem trhliny.

V předchozí studii [18] nastalo ověření správnosti hodnot výsledků kalibrací těles zatížených tříbodovým ohybem. Nejprve byli hodnoty součinitele napětí pro dvourozměrné těleso získané se softwarového prostředí různýma metodami porovnané s výsledky dosaženými použitím vztahů z literatury [11], [16], výsledné hodnoty prokázali dostateční přesnost, viz Obr. 3. Následně došlo k porovnání dvourozměrného tělesa s třírozměrným tělesem konstantního průřezu, a I profilu s rovným čelem, prorůstajícím celou tloušt'kou průřezu, výsledky čeho jsou znázorněny na Obr. 4. Hodnoty pro IPE vykazovali výrazněji prudší růst v oblastech, kde svislý rozměr trhliny překročil polovinu tloušt'ky stojiny. Následovalo porovnání výsledků modelů IPE s různými tvary čel trhliny, které je znázorněno na Obr. 5. Hodnoty pro rovné čelo výrazněji převyšovali zbylé tři př́ípady, kde růst hodnot probíhal s mírnější tendencí.

\section{VÝSLEDKY A DISKUZE}

Podle výsledků únavových zkoušek na CT tělesech, uvedených v článku [4], byla pro parametr asymetrie $\mathrm{R}=0,1$ změřena prahová hodnotu $\Delta K_{t h}=7 \mathrm{MPa} \sqrt{\mathrm{m}}$. Pro každý tvar trhliny bylo pak nalezeno zatížení, kdy nastává hodnota součinitele intenzity napětí ve vrcholu trhliny blízká uvedené mezi. Hodnoty síly aplikované na model pro získání $K_{t h}$ jsou uvedeny v tab. 2. Nejvyšší síla byla aplikována pro trhlinu s nejmenší plochou, u čtverečního a rovného čela se hodnoty rovnaly a na rozmezí byla eliptická plocha. Po dosažení hodnota působícího zatížení nebyla měněna, naopak rostla poměrově délka trhliny $a$ ve směru rovnoběžném s působícím zatížením poměrově $\mathrm{k}$ tloušt'ce pásnice $t$. Následně byly určené počty cyklů nutné pro růst $\mathrm{v}$ jednotlivých krocích $\mathrm{d} N$, které se zmenšovali s větším rozměrem trhlin, co vycházelo z předpokladu únavového chování materiálu. Závislost počtu cyklů na rozměru trhliny je znázorněná na Obr. 6.

V počátku byla zvolena hodnota přibližující se mezi únavy pro ocel, pro vyvození růstu trhliny. Následně byli hodnoty n, pro počet cyklů $10^{\mathrm{n}}$ snižovány lineárně. Výsledná závislost $K$ na poměru $\mathrm{d} a / \mathrm{d} N$ je v logaritmickém 
měřítku znázorněná na Obr. 7. Výsledky znázorňují nejmenší nárůst hodnot součinitele intenzity napětí pro kruhový tvar, naopak na druhé straně stojí trhlina s rovným čelem prorůstající celou tloušt'kou průřezu. Pro všechny tvary se křivky závislosti dají dostatečně přesně aproximovat lineární závislostí, která vzhledem na logaritmické souřadnice je křivka mocninové funkce. Z grafického znázornění je pak možno vyjádřit vztah odpovídající Parisovu zákonu.

Tab. 2 Hodnoty síly potřebné pro získání prahové hodnoty $\Delta \mathrm{K}_{\mathrm{th}}=7 \mathrm{MPa} \mathrm{m}^{1 / 2}$

\begin{tabular}{ccccc}
\hline & Rovné čelo & Čtverec & Elipsa & Kruh \\
\hline $\mathrm{P}[\mathrm{kN}]$ & 48,18 & 48,18 & 58,08 & 62,04 \\
\hline
\end{tabular}

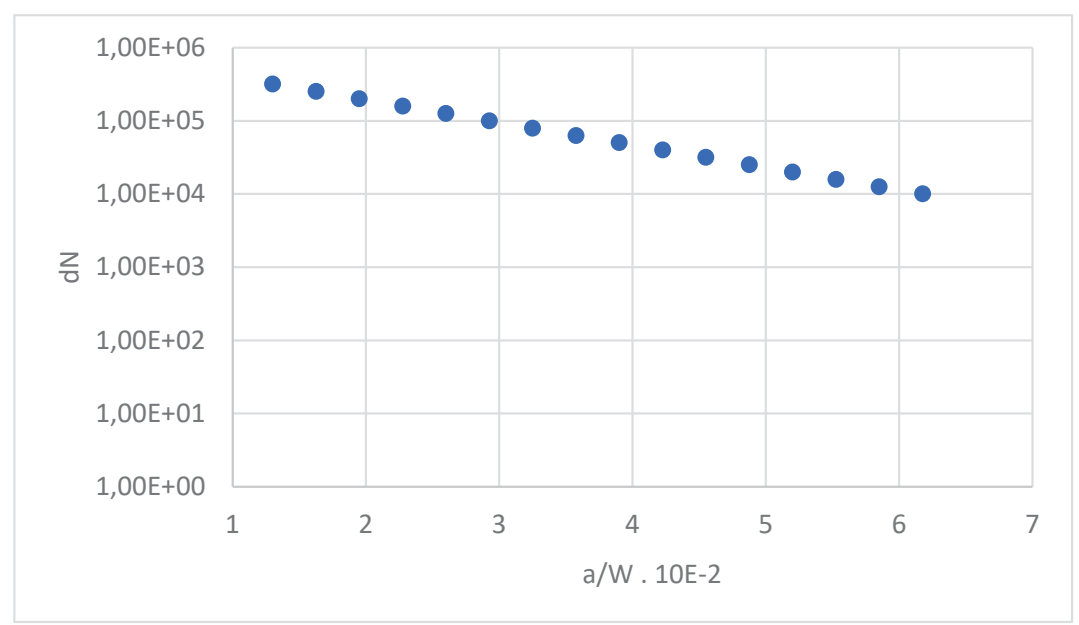

Obr. 6 Počet cyklů v závislosti na relativní délce trhliny.

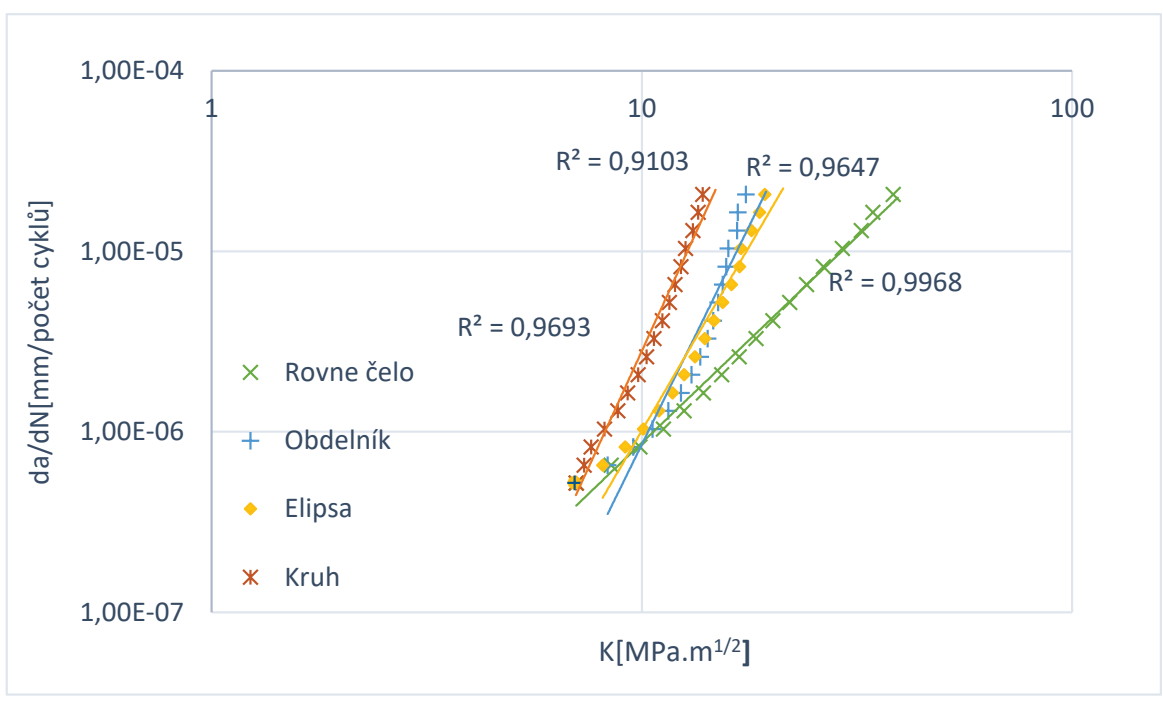

Obr. 7 Závislost rychlosti růstu trhliny na součiniteli intenzity napětí pro různé tvary čela trhliny.

Dosažené hodnoty dobře korespondovali s dříve dosaženými výsledky, kdy nejvy̌ší hodnoty součinitele intenzity napětí dosahovalo rovné čelo trhliny, následované tvarem elipsy, tvarem obdélníkovým a nakonec kruhovým. Rychlost šíření únavové trhliny byla zvolená stejná pro všechny variace. Přesnost lineárního proložení závislosti 
hodnotou spolehlivosti je uvedena v grafu na obrázku 7 při jednotlivých křivkách. Nejvyšší podobnost lineární křivky je u čela rovného, naopak nejnižší u obdélníkového tvaru.

\section{ZÁVĚR}

V práci byla na základe předpokladů únavového chování materiálů odhadnuta rychlost šíření únavové trhliny v IPE z nerezové oceli AISI 304. Pro dosažení meze součinitele intenzity napětí pro šíření únavové trhliny byla pro čtyři tvary čela trhliny vyčíslena síla aplikovaná v tříbodovém ohybu. Vzhledem na možnost použití Parisova zákona, byli rychlosti šírení $\mathrm{v}$ oblasti středních hodnot. Výsledná závislost da/dN na $\mathrm{K}$ dobře korespondovala s praktickými experimenty na nerezové oceli ve studii [4] a závislosti vykazovali dostatečnou přesnost pro určení lineární závislosti hodnot rychlosti růstu trhliny a součiniteli intenzity napětí. Výsledky práce budou následně porovnány s výsledky z experimentálního šíření únavové trhliny v IPE nosnících.

\section{Poděkování}

Finanční podporu Fakulta stavební No. FAST-S-21-7338) a GAČR projekt číslo: 20-00761S - Vliv materiálových vlastností korozivzdorných ocelí na spolehlivost mostních konstrukcí.

\section{Zdroje}

[1] GARDNER, Leroy. The use of stainless steel in structures. Progress in Structural Engineering and Materials. 2005, 7(2), 45-55. ISSN 1365-0556. Dostupné z: doi:10.1002/pse.190.

[2] BADDOO, N.R. Stainless steel in construction: A review of research, applications, challenges and opportunities. Journal of Constructional Steel Research. 2008, 64(11), 1199-1206. ISSN 0143974X. Dostupné z: doi:10.1016/j.jcsr.2008.07.011

[3] GEDGE, Graham. Structural uses of stainless steel — buildings and civil engineering. Journal of Constructional Steel Research. 2008, 64(11), 1194-1198. ISSN 0143974X. Dostupné z: doi:10.1016/j.jcsr.2008.05.006

[4] ANDERSON, T. L. Fracture mechanics: fundamentals and applications. Fourth edition. Boca Raton, [2017]. ISBN 978-1-4987-2813-3.

[5] JAMBOR, Michal, Tomáš VOJTEK, Pavel POKORNÝ a Miroslav ŠMÍD. Effect of Solution Annealing on Fatigue Crack Propagation in the AISI 304L TRIP Steel. Materials. 2021, 14(6). ISSN 1996-1944. Dostupné z: doi:10.3390/ma14061331

[6] SEITL, Stanislav, Pavel POKORNÝ a Jan KLUSÁK. Effect of specimen thickness on fatigue crack growth resistance in Paris region in AISI 304 STEEL,2021

[7] SEITL, Stanislav, Petr MIARKA a Zdenek KALA. Geometry Functions for Edge Cracks in Steel Bridge under Three- and Four- Point Bending with Various Span. Transactions of the VŠB - Technical University of Ostrava, Civil Engineering Series. 2019, 18(2). ISSN 12131962. Dostupné z: doi:10.31490/tces-2018-0015

[8] MALVAR, L. J., G. E. WARREN a Zdenek KALA. Fracture energy for three-point-bend tests on singleedge-notched beams. Experimental Mechanics. 1988, 28(3), 266-272. ISSN 0014-4851. Dostupné z: doi:10.1007/BF02329022

[9] BRAET, Lucas, Tereza JUHÁSZOVÁ, Daniel JINDRA, Petr MIARKA a Stanislav SEITL. Finding the optimal stress state of a stainless-steel IPE profile for fatigue experiments. Procedia Structural Integrity. 2021, 33, 1065-1072. ISSN 24523216. Dostupné z: doi:10.1016/j.prostr.2021.10.118

[10] INEREZ.CZ: Nerezový materiál a zařízení [online]. 2021 [cit. 2021-11-26]. Dostupné z: https://www.inerez.cz/jakosti-nerezovych-materialu/

[11] IRWIN, G.R. Analysis of Stresses and Strains Near the End of a Crack Traversing a Plate. Journal of Applied Mechanics, pp.361-364, 1957.

[12] TADA, Hiroshi, Paul C. PARIS a George Rankin IRWIN. The stress analysis of cracks handbook. 3rd ed. New York: ASME Press, c2000. ISBN 978-0-7918-0153-6.

[13] MURAKAMI, Y. Stress Intensity Factors Handbook. Volume 5. Oxford: Pergamon Press, 2001. ISBN 49-013-8111-3.

[14] PARIS, P. C., M. GOMEZ a W. ANDERSON. A rational analytic theory of fatigue. The trend in Engeneering. 13, 9-14, 1961.

[15] KUNZ, J. Lineární lomová mechanika - možnosti a omezení aplikace při výzkumu šíření únavových trhlin. In: Letná škola únavy materiálov '2004. Žilina: Žilinská univerzita, 2004, s. 33-43. ISBN 708070-283-7. 
[16] KUNZ, Jiří. Základy lineární a nelineární lomové mechaniky pro inženýrskou praxi. Praha: Česká technika - nakladatelství ČVUT, 2020. ISBN 978-800-1066-720.

[17] POOK, L. P. Lineární elastická lomová mechanika pro konstruktéry: teorie a aplikace. Brno: Vysoké učení technické v Brně, nakladatelství VUTIUM, 2017. ISBN ISBN978-802-1447-608.

[18] JUHASZOVA, T., MIARKA, P., SEITL, S.: Analysis of stress field shape around crack tip in stainless steel IPE beam, Modelling in Mechanics, 19th International Conference, 2021 (in press). 